\title{
Zur Morphologie der
}

Larvenstadien einiger parasitischer Hymenopteren des Grauen

Lärchenwicklers(Zeiraphera

griseana Hübner)

\section{Doctoral Thesis}

Author(s):

Gerig, Luzio

Publication date:

1960

Permanent link:

https://doi.org/10.3929/ethz-a-000153722

Rights / license:

In Copyright - Non-Commercial Use Permitted

Originally published in:

Beiträge der wissenschaftl.Arbeitsgemeinschaft zur Erforschung der Populationsdynamik des Grauen Lärchenwickler 12 
Prom.Nr.2927 B. Diss ETH

Zur Morphologie der Larvenstadien einiger parasitischer Hymenopteren

des Grauen Lärchenwicklers

(Zeiraphera griseana Hübner)

\author{
VON DER \\ EIDGENƠSSISCHEN TECHNISCHEN \\ HOCHSCHULE IN ZURICH \\ ZUR ERLANGUNG \\ DER WURDE EINES DOKTORS \\ DER TECHNISCHEN WISSENSCHAFTEN \\ GENEHMIGTE \\ PROMOTIONSARBEIT
}

VORGELEGT VON

LUZIO GERIG

DI P L. I NG. - A GR.

VON ZURICH

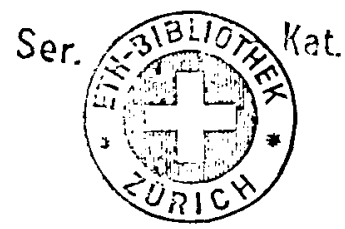

Referent: Herr Prof. Dr. P. Bovey

Korreferent: Herr Prof. Dr. H. UlRICH

1960

Drudk: Westholsteinische Verlagsdrudkerei Boyens \& Co., Heide/Holstein 


\section{Zusammenfassung}

1. Im Rahmen der Arbeitsgemeinschaft zur Erforschung der Populationsdynamik des Grauen Lärchenwicklers im Engadin wurde die Larvenmorphologie der wichtigsten parasitischen Hymenopteren der beiden Formen von Zeiraphera griseana Hübner (Lärchen- und Arvenform) abgeklärt und beschrieben. Es betrifft dies die folgenden Parasiten-Larven:

Ektoparasiten: Phytodietus spec. $A$.

Eclytus fontinalis Hlgr.

Endoparasiten: Horogenes exareolatus Ratz.

Triclistus spp.

Phaeogenes osculator Thunb.

Pimpla turionellae $\mathrm{L}$.

Pimpla cf. melanacrias Perk.

Pimpla arctica Zett.

Itoplectis alternans var. kolthoffi Auriv.

Itoplectis griseana Perk.

2. In der Literatur besteht keine einheitliche Terminologie der Larven-Kopfkapsel-Elemente. Es wurde eine vergleichende Ubersicht über die bisher verwendeten Termini gegeben und ein Kopfkapsel-Schema entwickelt, das sich auf Ichneumonoidea und Chalcidoidea anwenden läßt.

3. Zur Auseinanderhaltung der sehr schwach differenzierten Elemente der Kopfkapsel wurde eine geeignete Untersuchungs-, Präparierungs- und Färbemethode eingeführt.

4. Die Ls-Larven der untersuchten Parasitenlarven lassen sich mit Hilfe des aufgestellten Schlüssels bestimmen. Für die Bestimmung der ersten vier Larvenstadien sei auf die entsprechenden Figuren verwiesen.

5. Sämtliche untersuchten Parasitenlarven konnten auf Grund ihrer morphologischen Unterschiede teils nach makroskopischen, teils nach mikroskopischen Kriterien bis zur Art determiniert werden (Ausnahme: Triclistus spp.).

6. Für einige Arten wurde die Morphologie der Eier beschrieben.

\section{Résumé}

1. Dans le cadre des recherches du groupe de travail pour l'étude de la dynamique des populations de la Tordeuse grise du mélèze en Engadine, la morphologie des larves des plus importants hymenoptères parasites des deux formes de Zeiraphera griseana Hübner a été clarifiée et décrite. Les larves étudiées sont les suivantes:

Ectoparasites: Phytodietus spec. A.

Eclytus fontinalis $\mathrm{Hlgr}$.

Endoparasites: Horogenes exareolatus Ratz.

Triclistus spp.

Phaeogenes osculator Thunb.

Pimpla turionellae $\mathrm{L}$.

Pimpla cf. melanacrias Perk.

Pimpla arctica Zett.

Itoplectis alternans var. kolthoffi Auriv.

Itoplectis griseana Perk. 
2. La littérature ne présente aucune unité en ce qui concerne la terminologie des éléments de la capsule céphalique. Nous avons donné un tableau comparatif des termes précédemment utilisés; de plus un schéma des éléments de la capsule céphalique a été mis au point pour les Ichneumonides et les Chalcidiens.

3. Pour l'examen des éléments de la capsule céphalique très peu différenciés, nous avons introduit des méthodes appropriées d'examen, de préparation et de coloration.

4. Nous avons élaboré une clef de détermination pour les larves du cinquième stade. Les caractères morphologiques des quatre stades précédents peuvent être précisés d'après les figures correspondantes.

5. Toutes les larves des parasites étudiés peuvent être déterminées au moyen de distinctions macro- et micromorphologiques, ceci jusqu' à l'espèce, à l'exception des Triclistus spp.

6. Pour quelques espèces, la morphologie des oeufs a été spécialement décrite.

\section{Summary}

1. Research on the morphology of the larvae of the hymenoptera parasites of the larch-bud moth was conducted as a part of the team-work research undertaken to investigate the population dynamics of this pest in Engadine. The most important ecto- and endoparasites of both forms of the Zeiraphera griseana Hübner have been considered, investigated and described. This concerns the larvae of the following parasites:

Ectoparasites: Phytodietus spec. A.

Eclytus fontinalis Hlgr.

Endoparasites: Horogenes exareolatus Ratz.

Triclistus spp.

Phaeogenes osculator Thunb.

Pimpla turionellae L.

Pimpla cf. melanacrias Perk.

Pimpla arctica Zett.

Itoplectis alternans var. kolthoffi Auriv.

Itoplectis griseana Perk.

2. Up to now, no unity could be brought into litterature as to the terminology of the head-capsule elements. A comparative survey of the terms formerly used, together with a schematic set-up of the head capsule, have been developped.

3. For the study of the very slightly differenciated structures from the larvae-head a method of investigation, preparation and coloration of these elements has been elaborated.

4. For the identification of final instar of Ichneumonidae- and Chalcididaelarvae a key has been worked out. The morphological characters of the first four instars may be grasped by a comparative study of the corresponding figures.

5. All of the studied larvae of parasites could be identificated by macro- and micromorphological characters. The only exception has been the Triclistus spp.

6. The morphology of the eggs of a few species has been specially described. 